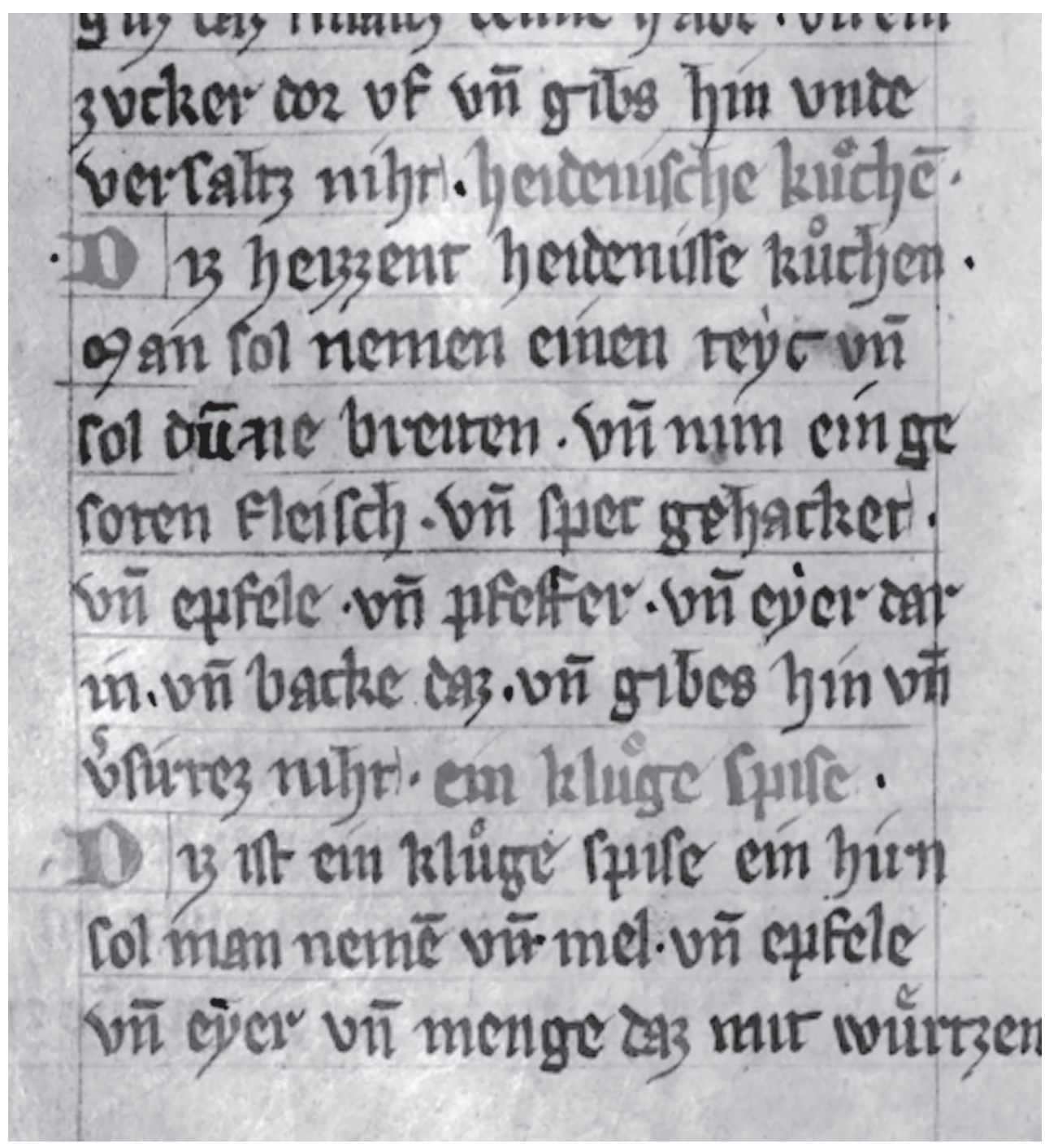


ERMi aastaraamat 60 (2017), lk 16-33

DOI: 10.33302/ermar-2017-001

\section{Paganate kookidest seakõrvadeni. Transkultuuriline rännak ühe toidu jälgedes läbi sajandite ja kokaraamatute*}

Inna Põltsam-Jürjo

\section{Alustuseks}

Tänases Eesti köögis leidub päris palju toite, olgu selleks rukkileib, verivorst, hapukapsas jms, mis on siinmail elanud inimeste menüüs püsinud juba sajandeid, kohati tuhat või rohkemgi aastat. Kahtlemata on toidud ajas muutunud, iga ajastu on toonud kaasa oma eelistusi maitsenüansside, vormi jne osas, rääkimata juba igast üksikust toiduvalmistajast lähtunud eripäradest, tema individuaalsusest. Nii näiteks ei lisatud eesti taluperes rukkileivataignale kaua aega soola ning tänapäevasega võrreldes küpsetati 18.-19. sajandi talus lausa hiiglaslikke, 5-12 kg kaalunud leivapätse (Moora 1991: 163, 171-172; vrd Põltsam-Jürjo 2012: 21, 24). Kuidas maitses üks või teine praegugi tuttav toit sadu aastaid tagasi, on võimatu täpselt teada saada, kuivõrd maitset ei suuda ükski ajalooallikas talletada. Siiski juhatavad säilinud vanad retseptid toiduajaloo uurijaid või muidu huvilisi vähemalt kunagiste toitude võimalike maitsete ja muude omaduste tundmise poole.

Kõige paremini aitab toitude retsepte ja nimesid läbi sajandite alal hoida kirjalik jäädvustamine. Kirjasõna lugu Eestis algab keskajal, just sellest ajastust pärinevad ka varaseimad ülestähendused tollases peenes, kõrgseltskondlikus köögis tuntud roogade nimetustest kohalikes allikates. Kui keskaja Euroopast on alles mitmeid kokaraamatuid, siis Eestist pole paraku ühtegi retseptikogu teada. Siinsetest kirjalikest allikatest tuleb esile vaid paari Euroopas laiemalt, s.o regioonideüleselt tuntud

* Käesolev artikkel on valminud uurimisprojekti IUT31-6 „Eesti ajaloo rahvusülene raamistik: transkultuurilised põimingud, ülemaailmsed organisatsioonid ja piiriülene ränne (16.21. saj)" raames.

Foto 1. Paganate kookide retsept 14. sajandi käsikirjalises kokaraamatus “Daz buch von guter spise". Münchener Universitätsbibliothek, Cim 4 (=2o Cod. ms. 731), fol 156 p. 
roa nimi, nagu näiteks mandlipüree või paganate koogid (Põltsam-Jürjo 2013: 129, 192). Mõnevõrra paremini on läinud jookidega, nimelt on Tallinnast 16. sajandi esimesest poolest säilinud koguni kaks kogu Euroopas hinnatud ja armastatud vürtsveini klareti retsepti. Need pole aga talletatud mõnes retseptikogus, vaid hoopis rae arve- ja märkmeraamatus (TLA, Ad 32: 30p; Bunge, Paucker 1851: 112). Kuigi keskaja kokaraamatuid ja retseptikogusid pole Eestist säilinud, ei tähenda see veel nende puudumist omal ajal. Küllap pandi kirja nii eelpool mainitud mandlipüree kui ka paganate kookide retsepte. Trükikunsti levides jõudsid raamatukaupmeeste vahendusel Eestisse Saksamaal trükivalgust näinud kokaraamatud. Näiteks leidus 1601. aastal Tallinna elaniku Heinrich Matssoni pärandvara hulgas 1581. aastal Frankfurdis ilmunud Max Rumpolti „Ein new Kochbuch” (TLA, Aa 44: 125). Paraku on kokaraamatute vanem ajalugu Eestis peaaegu uurimata teema. Puudub isegi selge ettekujutus, palju on üldse säilinud 18. sajandile eelnenud ajast käsikirjalisi retseptikogusid või kuivõrd on mujal Euroopas ilmunud kokaraamatuid jõudnud Eestisse. Põhjalikum ülevaade on Eesti publikule ja eesti keeles ilmunud kokaraamatutest 18. sajandist teisest poolest alates (vt nt Viires 1985). ${ }^{1}$ Esimesed eestikeelsed kokaraamatud ei ole väärtuslikud ainult toiduajaloo allikatena, vaid ka vanema keele ja kirjanduse mälestusmärkidena. Alates 19. sajandist tõusis konkreetselt Eesti publikule suunatud algupäraste kokaraamatute arv järjepidevalt ja on nüüdisajal üks populaarsemaid kirjandusžanre.

Retseptikogud ja kokaraamatud on väärtuslikud ajalooallikad, tõsi küll, rahva toitumise uurimiseks jääb nendes sisalduvast infost väheseks (vrd Albala 2012: 229 jj). Eriti vanemad kokaraamatud olid mõeldud pigem ülemkihtidele ning peegeldasid nende toitumistavasid. Leidub siiski mitmeid toidukultuuri aspekte, mida just kokaraamatud parimal võimalikul viisil valgustavad. Muuhulgas annavad need tunnistust regioonideülesest kultuurivahetusest, samuti kulinaarsest mobiilsusest ja kommunikatsioonist, olgugi et pikka aega haaras rahvusvahelisus ja kultuurideülesus Euroopas, sealhulgas Eestis eeskätt ülemkihi kööki. Hiljemalt 19. sajandil ilmusid kokaraamatud, mis kajastasid juba spetsiifilist regionaalset kööki (Schubert 2006: 298). Teatud piiratusest hoolimata vahendavad ajaloolised kokaraamatud rikkaliku informatsiooni toidukultuuri kohta, nagu näiteks teavet uudsete toorainete kasutuselevõtust, maitsesuundumustest, toiduretseptide levimisest, valmistamisviiside muutumisest, kokakunsti aktuaalsetest eeskujudest, samas ka kulinaarse terminoloogia arengust jm.

Toiduajaloo seisukohalt intrigeeriv on leida Eesti 19.-20. sajandi retseptikogudes samu, s.o samade nimedega roogi, mis esinevad juba 14.-15. sajandi Euroopa kokaraamatutes. Selline vastupidavus ajas on tähelepanuväärne, ärgitades nähtust lähemalt uurima. Kas aga sama nimetus tähistab igal pool ja alati sedasama rooga, on esimene küsimus, mis selles seoses tõstatub. Ehk teisiti öeldes, kas ajas on jäänud püsima ainult roa nimi või ka retsept? Niisamuti väärib tähelepanu, mis ajendas muutusi ühe või teise roa valmistamise traditsioonis. Käesolevas kirjatöös

[1] Seni parima ülevaate eesti vanimatest kokaraamatutest ja köögikirjanduse arengust pakub Eesti Rahvusraamatukogus Urve Sildre ja Helle Remmelti 2007. aastal koostatud näitusega „Kasuline kokaraamat“ koos valminud virtuaalnäitus (Urve Sildre), vt https://www. nlib.ee/html/expo/kokaraamat/saat.html. 
on võetud vaatluse alla üks konkreetne roog - nn paganate koogid -, mille retseptid pärinevad eri ajastute kokaraamatutest ja retseptikogudest. Eesmärgiks on välja selgitada, millised muutused ja arengud (või vastupidi püsimajäämised) on toimunud selle roa rändamisel ühest ajastust teise ning kokaraamatust kokaraamatusse. Ühe roa nii pikk ajalugu Eesti köögis, selle püsimine retseptikogudes sajandeid kuni nüüdisajani välja, on juba iseenesest põnev fenomen ning väärib lähemat uurimist.

\section{Paganate koogid - keskaja retsept}

Kõige varasem teade nn paganate kookide valmistamise kohta Eestis pärineb 1511. aastast. Nimelt nähtub Tallinna rae vastlapeo arvest, et sellel puhul korraldatud pidusöögiks on kokk valmistanud muu hulgas "paganate kooke“ (heydenssche koken). Selle tarvis osteti jahu, pipart ja safranit ning ilmselt ka võid (TLA, Ba 6: 277). Koogi valmistamise retsepti peoarve paraku ei paljasta. Tallinna rae pidusöömingud paistsid silma luksuslikkuse ja rikkalikku toiduvaliku poolest, ka paganate kookide pakkumine sobitub sellesse pilti hästi, kuivõrd tegu oli Euroopa peenes köögis laiemalt tuntud roaga, mille valmistamisõpetuse võib leida mitmest keskaegsest Saksa kokaraamatust.

Paganate kookide vanim teadaolev retsept esineb 14. sajandi keskpaigast pärinevas esimeses saksakeelses retseptikogus „Daz buch von guter spise”, tuntud ka kui Würzburgi kokaraamat. Vanas saksa keeles tähendas heidenische peale pagana, paganliku, ka võõramaist, idamaist, see oli osutus kreeka, saratseeni päritolule (Wiswe, Hepp 1970: 209). Väärib märkimist, et nimetatud retseptikogus on veel teisigi toite, mille nimetuses sisaldub heydenisch, nagu näiteks paganate ehk idamaised herned, samuti pagana ehk saratseeni pea (Gloning 2001: 63, 95). Selles võib näha idamaa köögi mõjutusi tolle aja Euroopa kokakunstile. Kokaraamatus „Daz buch von guter spise" toodud retsepti järgi tuli paganate kookide valmistamiseks teha koogitainas, rullida see õhukeseks, panna vormi. Koogi täidiseks tuli tükeldada keedetud liha ja peekon, segada juurde tükeldatud õunad, paar muna ning maitsestada saadud segu pipraga; valada see ettevalmistatud koogivormi ja küpsetada (Gloning 2001: 5a). Nii et see oli lihatäidisega (vormi)pirukas.

Kas Tallinna paganate koogid võisid olla valmistatud selle retsepti järgi? Võrreldes rae vastlapeo arves toodud koogi koostisosi, on näha, et kokkulangevusi peale pipra ja jahu nendes ei ole. Muidugi tuleb arvestada, et allikas on arve, mistõttu ei saa olla täiesti kindel, et seal olid n-ö ühele reale ära märgitud kõik koogi koostisosad. Pidusööminguks varuti hulgaliselt mitmesuguseid toiduaineid, nii et pirukatäidiseks vajalik liha võis tulla ka n-ö arve teise rea alt.

Kuid on teinegi võimalus. Nimelt ühes 15. sajandist säilinud Saksa retseptikogus „Maister Hanns des von Wirtenberg Koch, Guot Ding von allerlay Kochen” (1460) seisab paganate ehk ida- või hommikumaiste kookide nime all hoopis teistsuguse toidu retsept. Munaga valmistatud koogitainas tuli rullida õhukeseks nagu oblaadi puhul, lõigata sellest kolme sõrme laiused ja käelaba pikkused tükid, küpsetada need rasvas ja valada seejärel üle pipraga maitsestatud meejoogi või -siirupiga (Wiswe, Hepp 1970: 209). Kokakunsti kultuuriajaloo uurijate Hans Wiswe ja Eva 
Heppi teoses väidetakse, et nimetatud retsepti järgi valminud küpsetis on sarnane nn Kleopatra saiakesele (türgi k tulumba) (Wiswe, Hepp 1970: 209). Nähtub, et paganate koogi puhul polnud tegu ühe konkreetse roaga, vaid selle nime all tunti Euroopa peenes köögis erinevaid küpsetisi. Mõlemal juhul osutas roa nimi algsele eeskujule ja päritolule. Tõenäoliselt ei eraldanud kahte mainitud kokaraamatut terve sajand, kuna meister Hannsu 15. sajandi retseptikogu on ärakiri mingist tunduvalt varasemast käsikirjast (Wackernagel 1853: 365). Nähtavasti jõudsid mõlemat sorti paganate koogid üsna üheaegselt peenesse, kõrgseltskondlikku kööki.

Kas Tallinna rae vastlapeoks valmistatud paganate koogid võisid pigem lähtuda meister Hannsu retseptist, jääb andmete vähesuse tõttu ikkagi kindla vastuseta. Niisamuti jääb teadmata, kas paganate kookide valmistamise näol 1511 oli tegu erandjuhusega või traditsiooniga. Koogid kuulusid vaieldamatult eliidi pidusöökide menüüsse, kuid kirjalikes allikates pole neid lähemalt määratletud. Heal juhul tulevad ilmsiks nende koostisained. Näiteks on Tallinna Suurgildis pidulikuks söömajaks valmistatud kooke jahust, piimast, võist, piprast, safranist, erandjuhul ka aniisist (TLA, 191.2.19: 25, 28). Jällegi on andmete vähesuse tõttu võimatu öelda, kas tegu võis olla näiteks paganate kookide kohaliku, s.o Tallinna variandiga või siiski pigem mingi teise küpsetisega. Igatahes näitavad uurimused, et kuigi keskaja Euroopa peenes köögis olid laenud tavalised, polnud kunagi tegu üks-ühese ülevõtmisega, vaid alati n-ö loomingulise laenamisega. Nii ilmutasid juba keskaja köögis end regionaalsed eripärad ja maitse-eelistused, mistõttu ei leidu sama nime kandvast toidust eri piirkondade kokaraamatutes ühtegi omavahel täiesti sarnast retsepti (Montanari 1999: 82).

Kuidas paganate kookide retsept Tallinna jõudis, seda saab ainult oletada. Vahendajaks võisid olla Saksa aladelt sisse rännanud kokad, samamoodi võis retsept jõuda keskaja Liivimaale kokaraamatuga, mille mõni hansakaupmees soetas Saksamaal või mille tõi kaasa mõni mööda hansa kaubateid liikunud raamatukaupleja. Kui laialdaselt neid küpsetisi keskajal Eestis valmistati, on võimatu öelda. Kuivõrd tegu oli peene köögi roaga, siis sai kookide nautijate ring piirduda ainult ühiskonna ülemkihiga - linnakodanike ja aadlikega -, lihtrahvas ei teadnud sellise nimega roast midagi, nende lauale ei jõudnud see kunagi.

\section{Esimene eestikeelne kokaraamat}

Paganate kookide eluiga Eesti peenes köögis ei piirdunud kaugeltki ainult keskajaga, tunnistuseks sellest on 18.-19. sajandi kokaraamatud. Tõsi küll, vähemalt seni puuduvad 17. sajandist teated nende küpsetiste valmistamise kohta, aga kas see osutab traditsiooni katkemisele või tuleneb pigem allikate spetsiifikast, on esialgu keeruline öelda. Igatahes leidub paganate kookide retsept 1781. aastal ilmunud esimeses eestikeelses kokaraamatus „Köki ja Kokka ramat”. Tegu on rootsi päritolu koka ja majapidaja Christina (Cajsa) Wargi (1703-1769) koostatud teosega, mis ilmus rootsi keeles 1755. Warg teenis Stockholmis mitme mõjuka isiku, sealhulgas von Stackelbergide aadliperekonna juures majapidajannana. Tema raamat sai Root- 
sis erakordselt populaarseks, nii et sajandivahetusel ilmus sellest juba üheteistkümnes trükk. Wargi teos tõlgiti ka saksa ja taani keelde. Saksa keeles anti raamat esimest korda välja 1772 Greifswaldis ning sajandi lõpul ilmus sellest kolmas trükk. Wargi teos oli peamiseks aluseks ka esimestele lätikeelsetele 1795. ja 1796. aastal eri väljaandjate koostatud ja avaldatud kokaraamatutele (Dumpe 1998: 234-236).

Wargi Saksamaal ilmunud teos levis kiiresti ka Eesti saksa ringkondadesse. Kokaraamatu praktiline väärtus hinnati koguni nii suureks, et see ajendas välja andma eestikeelset tõlget. Nagu on märgitud raamatu eessõnas, ei oska kõik kokad piisavalt saksa keelt, mistõttu monned ausad Herrad ja Prouad hakkasid tahtma, et retseptikogu saaks ka eesti keelde ümber pandud. Raamatu tõlkis originaalkeelest Noarootsi ja Reigi pastor Johann Lithander (1742-1789), kes oli sündinud Soomes ning õppinud Turu ülikoolis. Eestikeelne tõlge polnud mõeldud laiale publikule, vaid ainult professionaalsetele kokkadele („Eesti ma kokkade kassuks ja öppetuseks”), seepärast jäid välja mitmesugused majapidamisega seotud nõuanded, samuti riidevärvimisõpetus. Eestlastest kokad olid tol ajal mõisateenijatena tavalised, Wargi teose eestindamine pidi teenima nende oskuste ja teadmiste tõstmise ja uuendamise eesmärki. Olgu mainitud, et samal ajal avaldatud eestikeelne aiandusalane käsiraamat oli mõeldud samuti mõisas töötanud eesti soost aednikele, mitte edendama talurahva aiandust (Viires 1985: 159). Wargi eesti kokkade tarbeks tõlgitud kokaraamat ei aidanud siiski mitte ainult retsepte ja kulinaarseid teadmisi levitada, vaid väljendas ka Rootsi toidukultuuri mõju Eesti köögile.

„Köki ja Kokka ramatu” 986 retsepti hulgas leidub muuhulgas õpetus paganate kookide valmistamiseks ([Warg] 1781: 554, nr 761). Selle järgi tuli võtta 6 munarebu, lisada sinna kaks lusikat head rõõska koort või piima, suhkrut, head nisujahu ning valmistada sellest pehme tainas. Rullida tainas õhukeseks ning lõigata sellest koogirattaga kahe sõrme jämedused träämlid. Need tuli punuda kaks ja kaks krantsi wisi kokko. Koogid küpsetati võis. Retsepti lõppu on soovituseks lisatud, et wähhema kulloga saab, kui kasutada ka munavalgeid.

Wargi kokaraamatu tõlkimine eesti keelde on mitmes mõttes tähelepanuväärne: tegu oli 18. sajandil kõige ulatuslikuma eestikeelse tarbetekstiga, mis sekundeeris tol ajal mahukaimale usulisele kirjandusele. Toitude nimetused on raamatus toodud nii eesti kui ka saksa keeles, mõlemas keeles on koostatud register. See andis eestlastest kokkade saksa soost majaperemeestele samuti võimaluse mugavalt toiduvalikus orienteeruda. Kokaraamatu tõlkimine ei olnud Lithanderil kerge, sest kulinaarne terminoloogia polnud eesti keeles veel kuigivõrd arenenud, traditsiooni puudumise tõttu tuli paljud sõnad ja nimetused ise leiutada. Seetõttu leiab raamatust ohtralt uudissõnu: krääm (kreem), taart (tort), piskui (biskviit), pudding, pubbert jne (Viires 1985: 159). Just eesti ja saksa keeles paralleelselt esitatud roanimed muudavad Christina Wargi kokaraamatu käesoleva kirjatöö kontekstis eriti oluliseks. Nimelt leidub selles eestindatud nimevariandi klenätid saksa vastena Heidnische kuchen. Kui üksikud roanimed on Lithander eestindanud nende ligilähedase häälduse järgi, nt Katoo dö Selinott, siis nimetus klenätid on sisuliselt otse rootsi keelest (rts klenät) üle võetud. Kuna eesti keeles ei juurdunud kumbki nimetus, ei paganate koogid ega klenätid, siis Lithanderi tõlketa oleks keeruline neid üldse omavahel siduda. 
„Köki ja Kokka ramatu” ilmumist lahutab varaseimast teatest paganate kookide kohta Eestis täpselt 270 aastat. Kas ja mis oli ühist keskaja paganate kookidel 18. sajandi omadega? Võrreldes Wargi valmistamisõpetust kahe eespool toodud keskaja retseptiga, on selge, et ainuvõimalikuna seostub see Maister Hannsu variandiga. Mõlemal juhul on koogid valmistatud munataignast ning küpsetatud võis. Ka taignast lõigatud ribade laiuse mõõtmise sõrmede (Hannsul kolme ja Wargil kahe sõrme laiused ribad) abil võib mööndustega sarnasuste alla lugeda. Põhiline erinevus on maitses, Wargil on koogid ainult suhkruga maitsestatud. Maister Hannsul annavad maitset mesi ja pipar, Tallinna 1511. aasta teate järgi maitsestati paganate kooke pipra ja safraniga. Christina Wargi raamat on valminud tema enda kogemuste põhjal kokana töötades ning võib kindel olla, et ta ise paganate kooke või klenät'e valmistas, samas ei saa ainult retseptikogu olemasolu põhjal öelda midagi selle kohta, kuivõrd nende kookide valmistamine Eestis levis, retseptid on siiski ainult soovituslikud. Üldiselt kasutati „Köki ja Kokka ramatut” palju, nagu võib välja lugeda ca 40 aastat hiljem avaldatud Liivimaa kokaraamatu sissejuhatusest, kus märgitakse, et Wargi raamatust on saanud haruldus (nüüd wägga arwaste on sada) (Fehre 1825: III). Hoopis omaette küsimus on, kas nende kookide valmistamine 18. sajandilgi linnakodanike ja mõisaköökidest kaugemale levis?

Miks tõlgiti eesti keelde just Wargi teos ja mitte mõni muu? Kuivõrd initsiatiiv tõlke tegemiseks lähtus kohalikelt sakslastelt, siis mõjus ühelt poolt kindlasti teose menu Saksamaal, teiselt poolt ei olnud tähtsuseta küllap ka Wargi pikaajaline edukas teenistus Eesti- ja Liivimaa põlise aadlisuguvõsa von Stackelbergide juures Stockholmis. Tähelepanuväärsel kombel on Tartus Ajalooarhiivis säilinud suguvõsa Pidula liini kuulunud Karl Adam von Stackelbergi (1669-1749) perele kuulunud ning 1740. aastatel sisse seatud käsikirjaline retseptiraamat, mis paganate kookide nimelist retsepti paraku ei sisalda (EAA, 1862.1.90).

\section{Henriette von Wahli retseptikogu}

Kui oleks olemas vaid „Köki ja Kokka ramatu” teade paganate kookide ehk klenätide kohta, oleks selge, et see küpsetis jõudis 18.-19. sajandi Eesti kööki Skandinaavia kaudu. Pildi muudab aga mitmekesisemaks üks 19. sajandi algul koostatud käsikirjaline kokaraamat. Nimelt leidub lausa kaks retsepti paganate kookide valmistamiseks Henriette von Wahli (1782-1810) aastatel 1800-1810 kirja pandud retseptikogus. Henriette sündis Peterburis suurkaupmehe George Edwardsi perekonnas. 1802 abiellus ta Carl Gustav von Wahliga, kellega siirduti esialgu elama Tartusse, alates 1804. aastast aga seati end perega sisse Vana-Põltsamaa mõisas, mille rentnikud nad olid (Wahl 2014: 9, 11). Ilmselgelt vahendab see kokaraamat Henriette kogemusi mõisaprouana Põltsamaal.

Proua von Wahli küllaltki rikkalikus retseptikogus leiduva paganate kookide esimese valmistamisõpetuse järgi tuli võtta 16 muna, nendest 14 ilma valgeta ja 2 koos munavalgega, ning lisada jahu, et saaks õige pehme tainas. Veel läks vaja suhkrut, et kook saaks magus, kardemoni ning lõpuks safranit, et kook saaks kollane. Tainas tuli rullida päris õhukeseks, lõigata sellest koogirattaga välja parajad 
tükid ja küpsetada võis (Wahl 2014: 43). Retsept on piisavalt omanäoline, et lugeda seda iseseisvaks ja mitte Christina Wargi kokaraamatust pärinevaks. Mõlemal juhul on selgelt tegu munataignast rasvaküpsetistega, mille tainas on rullitud õhukeseks ja koogid lõigatud välja koogirattaga. Maitse ja värv oli neil aga täiesti erinev. Küpsetiste ja teiste toitude safraniga värvimine oli varauusaja ja uusaja baltisaksa köögis levinud, näiteks armastati küpsetada kollast kringlit. ${ }^{2}$ Väärib märkimist, et ka 1511. aastast Tallinnast pärit teate järgi kuulus paganate kookide koostisse kollast värvi andev safran.

Eriti põnev on Henriette von Wahli kokaraamatus leiduv paganate kookide teine retsept (Wahl 2014: 45). Selle järgi tuli võtta 50 muna, nendest 20 muna koos valgega ning 30 munakollast, iga muna kohta tuli lisada 2 lusikat magusat (rõõska) koort, veidi suhkrut. Tainas maitsestati 3 muskaadiga (muskaatpähkliga), veel võeti veidi muskaatõisi, kaneeli ja kardemoni. Lõpuks läks vaja veel 14 naela võid kookide küpsetamiseks. Mingil põhjusel on kõnealune retsept käsikirjas maha tõmmatud, kuid sellegipoolest pidi õpetus kusagilt pärinema ja proua von Wahlini jõudma. Eriliselt põnevaks teeb retsepti just rohke vürtside (muskaat, muskaatõied, kaneel, kardemon) kasutamine. Seejuures on kardemon maitseaineks mõlemas von Wahli kokaraamatus leiduvas retseptis. Vürtsidel oli keskaja kulinaarias tähtis roll, need olid seisuse ja prestiiži tunnusmärgiks, aga maitse muutus varasel uusajal Euroopa peenes köögis ning vürtsid kaotasid oma tähenduse, sest hakati eelistama pehmeid maitseid (Montanari 1999: 141-143). Selles mõttes on teine paganate kookide valmistamisõpetus eriti huvitav - see juhataks nagu tagasi keskaja köögi väärtuste juurde.

Eestis kohapeal koostatud käsikirjalised retseptikogud, mis on sündinud igapäevaelu kontekstis, on kohaliku köögikunsti osas tõlgitud kokaraamatutest kindlasti kõnekamad. Nendest võiks potentsiaalselt leida kohaliku köögi erijooni. Niisamuti ilmutab ennast toiduretseptides konkreetse majapidamise omapära, mille vajadustest lähtuvalt need on koostatud. Üheski laiale üldsusele mõeldud kokaraamatus vaevalt opereeritaks 50 munaga, nagu on Henriette von Wahli retseptis. Samas on see kogus kõnekas, näidates Vana-Põltsamaa mõisamajapidamise, sealse seltskondliku elu mastaape.

Kuivõrd Henriette von Wahli retseptid on Christina Wargi omast erinevad, siis tõenäoliselt pärinesid need mingist teisest allikast. Üks võimalus on Eesti kohapealse elava traditsiooni olemasolu paganate kookide valmistamisel. Tähelepanu väärib, et neid küpsetisi nimetati veel 19. sajandi algul paganate kookideks, mitte rootsi eeskujul klenät'ideks ega ka mitte Schürzkuchen (schürzen sks k sõlmima), nagu 1844. aastal ilmunud saksakeelses Mitau kokaraamatus (Praktisches Mitauer Kochbuch 1844: 219). ${ }^{3}$ Iseasi, kas see kohalik traditsioon püsis juba keskajast alates. Vähemalt esialgu on andmeid liiga vähe, et selle kohta midagi täpsemat arvata. Muidugi on ka võimalus, et keskaja paganate kookide valmistamise traditsioon katkes ning

[2] Stackelbergide perekonna 18. sajandi kokaraamatus leiduva retsepti järgi läks kollase võikringli valmistamiseks vaja piima, jahu, võid, muna, roosivett, safranit, suhkrut, muskaati, kardemoni, korinte ja rosinaid (EAA, 1862.1.90: 16).

[3] Retsepti järgi tuli võtta 6 munakollast, 6 lusikat magusat koort, 1 lusikas roosivett või selle asemel veidi kardemoni, 2 lusikat peensuhkrut, jahu nii palju, et saaks tainast rullida. Taignast tuli lõigata koogirattaga sobivad tükid, sõlmida kahekaupa kokku ja küpsetada võis (Praktisches Mitauer Kochbuch 1844: 219, nr 739). 
tuli varauusajal tagasi Skandinaavia köögi kaudu, kuid kohalik peen köök ei võtnud seda lihtsalt üle, vaid n-ö tõlkis oma keelde, lisades sinna need väärtused, mis talle olulised olid: vürtsid, kollase värvi. Samas, kui traditsioon oleks katkenud, siis kuidas seletada keskaegse nimetuse säilimist? Christina Wargi rootsikeelses

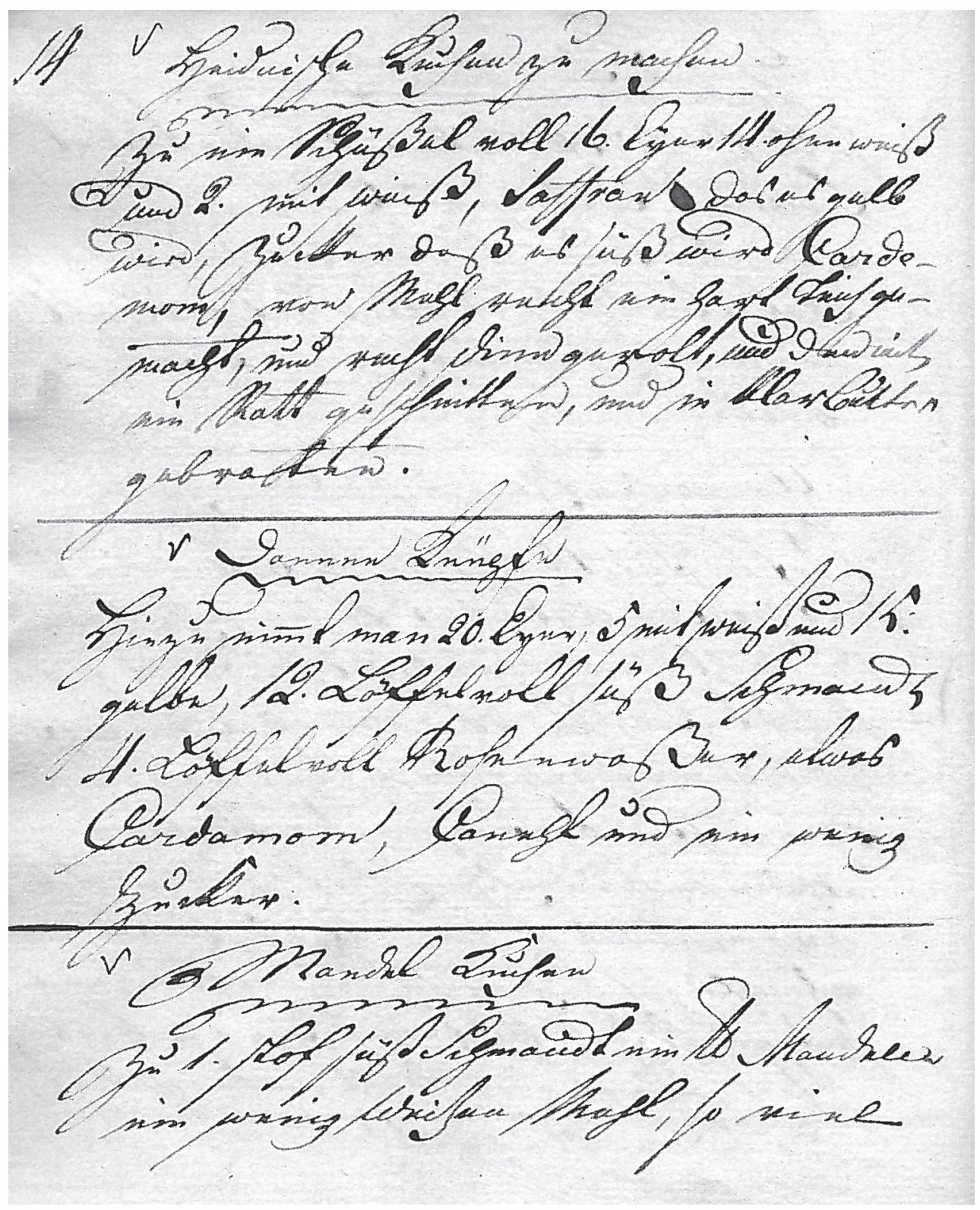

Foto 2, 3. Kaks paganate kookide retsepti Henriette von Wahli käsikirjalises kokaraamatus aastatest $1800-1810$. 
algupärandis on kookide nimeks klenät (Warg 1755: 436), mille Lithander "tõlgib“ Eesti- ja Liivimaa sakslaste jaoks paganate kookideks. Wargi 1772 Saksamaal ilmunud väljaandes nimetatakse neid kooke lihtsalt Ein kleines Gebäckels (Warg 1772: 381).

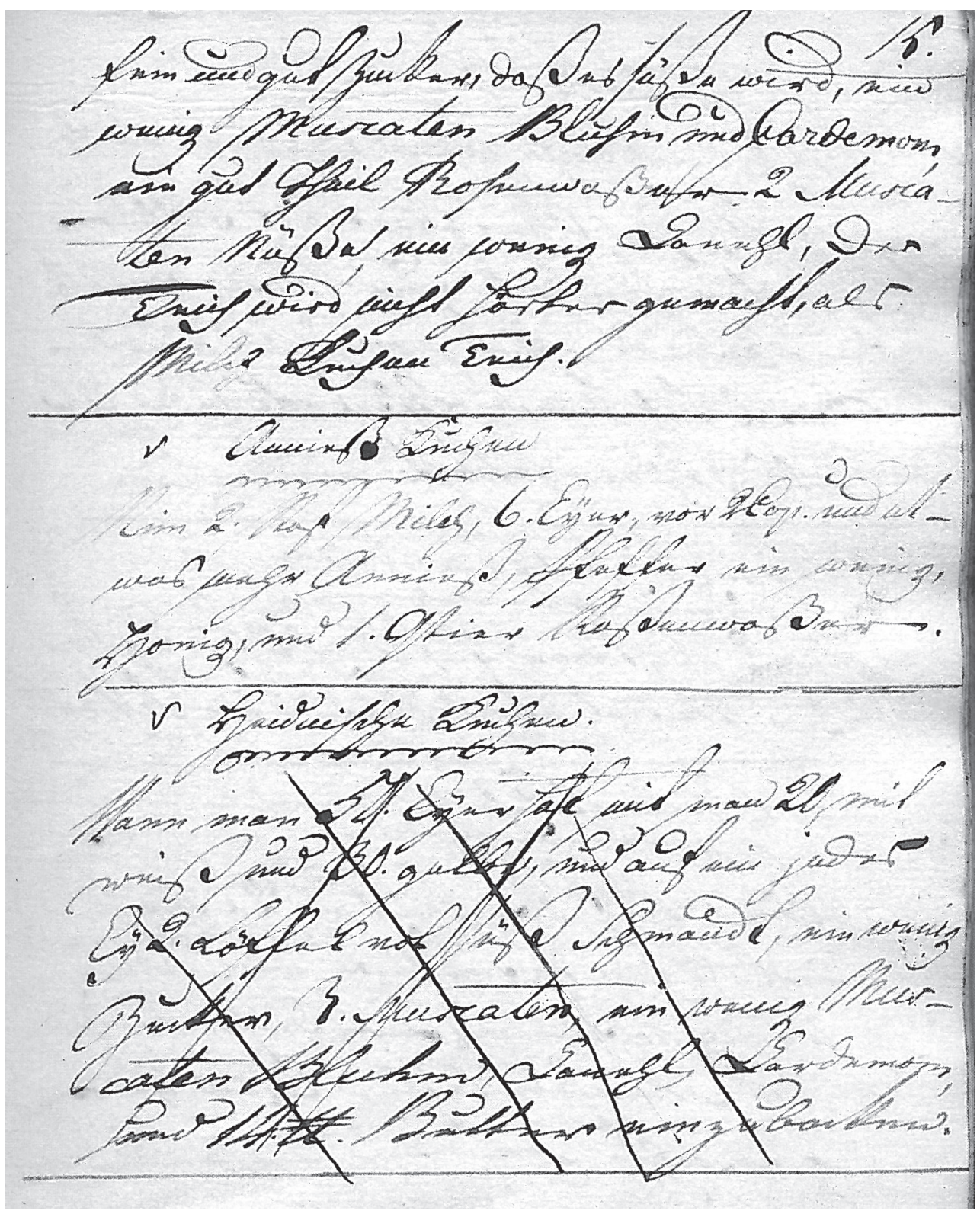




\section{9. sajandi trükitud kokaraamatud}

19. sajandil jõudis Eesti kokandusalane kirjandus uude ajajärku - ilmuma hakkasid kohalikud algupärandid. Esialgu olid need veel saksa keeles kirjutatud. Nii ilmus 1816 Riias Deubneri ja Treuy kirjastuses anonüümne „Livländisches Koch- und Wirtschaftsbuch". Kuigi Otto Wilhelm Masingu välja antud Marahwa NäddalaLehes seisab, et raamatu on kirjutanud "kulus roateggija Madam Sommer" (Marahwa Näddala-Leht 1825, nr 15: 118), siis nüüdisajal on autorina tuntud siiski Katharina Fehre (1766-1829). Erinevalt Christina Wargist oli Fehre kohalik, ta elas Riias ning töötas pärast mehe surma tütarlaste linnakoolis õpetajana. Oma viimased aastad (alates 1822) veetis ta aga Pärnus. Fehre retseptikogu oli kohalikes saksa ringkondades erakordselt populaarne, sellest avaldati juba ainuüksi tema eluajal viis kordustrükki. Kuid vajadus oli ka eestikeelse variandi järele. Marahwa Näddala-Lehe andmeil soovisid paljud lasta seda raamatut eesti keelde panna, sest eestlastest kokad ei mõistvat piisavalt saksa keelt, majaisandad jälle eesti keelt, nii ei suudeta vastastikku aru saada, kuidas üht või teist rooga valmistada (Marahwa Näddala-Leht 1825, nr 15: 119). Pastor Carl Matthias Henning (1774-1856) tõlkis teose ära ning see nägi trükivalgust aastal 1824 (1825) pealkirja all „Uus Kögi- ja Kokka ramat". 1851 ilmus kõnealune retseptikogu ka läti keeles.

Fehre koondab oma teosesse kohalikus peenes, kõrgseltskondlikus köögis liikunud retseptid. Kuivõrd leidub selles uusi originaalseid või Euroopa teistest kokaraamatutest laenatud õpetusi, see nõuab veel omaette uurimistööd. „Uus Kögi- ja Kokka ramat" sisaldab muu hulgas klenät' ide, s.o paganate kookide retsepti. Munakollastest, koorest ja jahust õpetati valmistama tainast, mis tuli maitsestada suhkru ja vähese kardemoniga, rullida õhukeseks ning lõigata see koogirattaga vastavalt soovile (missuggusiks tahhad) träämliks. Saadud träämlide otsad tuli „läbi lüüa“ ning küpsetada koogid öige pallava woi sees (Fehre 1825: 340). Fehre retsept on rohkem lähedane Christina Wargi kui Henriette von Wahli omale, Wargist erinev on siiski üks detail koogitaigna koostises - kardemon. Sarnane on ka mõlemal taigna lõikamine koogirattaga träämliks, kuid Fehrel pole enam juttu ribade kokkusõlmimisest. Fehre retsepti võib pidada Wargi kergeks muganduseks. Tuleb muuhulgas silmas pidada, et trükitud kokaraamat kui tolle aja kõige kaalukam meedium kokakunstis, hakkas oma reegleid dikteerima, mistõttu võisid lokaalsed eripärad taanduda. Katharina Fehre eestikeelses retseptikogus esinevad klenät'id juba ilma viiteta paganate kookidele ja see nimetus eesti keelde ei jõudnudki.

19. sajandi teisel poolel läks kõnealuste rasvaküpsetiste lugu Eesti köögis üha edasi. Aastal 1864 ilmus kolmas eestikeelne kokaraamat „Kasulinne kögi- ja majapiddamisseramat". Taas oli tegu saksakeelse algupärandi, s.o Lyda Pancki 1844 ilmunud teose "Kochbuch für die deutschen Ostseeprovinzen Russlands” tõlkega. See kokaraamat oli mõeldud spetsiaalselt linnakodanike majapidamistele, nõudlus ka eestikeelse variandi järele oli kooskõlas eestlaste osakaalu kasvuga linnarahvastikus. Pancki retseptide hulgas ei leidu õpetust ei klenät'ide ega paganate kookide valmistamiseks. Tõlkija Ferdinand Eckfeldti (1817-1864) vahendusel jõudsid need eesti publikuni seekord hoopis kui „rattakoogid“ (Rattakokid) (Panck 1864: 331), mis oli otsetõlge saksakeelsest nimetusest Räderkuchen (Panck 1862: 243) . Retsept ise 
ei ole võrreldes Wargi või Fehre omaga kuigivõrd muutunud, on lisandunud üks maitsenüanss, nimelt soovitatakse panna taignasse lisaks kardemonile ka sidrunikoort. Varasemast põhjalikum on selgitus kookidele õige väljanägemise või kuju andmise kohta: selleks tuli koogirattaga lõigata kahe sõrme laiused ja poolteise sõrme pikkused ribad, millele tehti keskele pikisuunaline lõige ning punuti koogi ots sealt paar korda läbbi (Panck 1864: 331).

Esimesed eestikeelsed algupärandid 19. sajandi viimastest kümnenditest, nagu Mats Tõnissoni, Jaan Koori ja Mai Reivelti kokaraamatud, ei vahenda ei rattakookide ega klenät'ide retsepte. See ei ütle muidugi veel midagi selle kohta, kas ja kui laialdaselt kõnealuseid rasvaküpsetisi tegelikult kodus valmistati. Nii Fehre kui Pancki kokaraamatud olid väga populaarsed. Näiteks Pancki raamatu eestindatud variandist ilmus 1901. aastal juba viies trükk, saksakeelset algupärandit tehti 1900 . aastani kaheksa trükki. Igal juhul võib selle raamatu mõju Eesti toidukultuurile oluliseks pidada (Viires 1985: 161). Ants Viires juhib ühtlasi tähelepanu, kuidas varased eestikeelsed kokaraamatud viisid rahvani Euroopa toidukultuuri väärtusi ja uudseid suundumusi, aidates sellega välja murda sajandeid püsinud endasse sulgunud talupoegliku elusfääri raamidest. Just selles näeb ta nende kokaraamatute kultuuriloolist sõnumit (Viires 1985: 166).

\section{Moodsa köögi retseptid}

Kokaraamatute põhjal otsustades jõudsid klenät'id ehk rattakoogid 20. sajandi algul eestlaste menüüsse. Selle retsepti levimisel rahva sekka oli kokaraamatute kõrval kaalukas roll ka populaarsetel majapidamis- ja keedukursustel. Alates 1901. aastast juhendas selliseid kursusi Adeline Tannbaum (1864-1942). Kindlasti suuresti tänu temale said kõnealused rasvaküpsetised eestlaste toidulaual laialt tuntuks, kuivõrd juba Tannbaumi 20. sajandi algul avaldatud retseptikogust võib leida nende valmistamisõpetuse (Tannbaum 1914: 77). Arvata võib, et neid kooke küpsetati ka Tannbaumi keedukursustel. Kookide valmistamisõpetus polnud võrreldes WargiFehre-Pancki ajaga kuigivõrd muutunud. Tannbaum uuendas siiski maitset, soovitades kasutada moodsamat maitseainet vanilli (Tannbaum 1914: 77), 1937. aasta variandis võis selle soovi korral asendada mõne tilga mandliõliga (Tannbaum 1937: 207). Tõeliselt märkimisväärse muutuse oli aga läbi teinud kookide nimi, nimelt klenät'idest ja rattakookidest olid saanud seakõrvad. ${ }^{4}$ Rahvas võttis selle nimetuse omaks ning sellisena on see püsinud tänaseni. 1914. aasta retsepti puhul väärib tähelepanu soovitus küpsetada koogid valmis kookosõlis (Tannbaum 1914: 77). Eriliselt hästi sobis seakõrvade retsept taimevõisid tutvustavatesse ja propageerivatesse üllitistesse, nii soovitab Tannabum neid oma 1927. aasta raamatukeses "Taimevõi majapidamises” "taimi sees keeta“ (Tannbaum 1927: 17-18). Seakõrvad esinevad Tannbaumi avaldatud retseptikogudes läbivalt, sealhulgas ka tema viimaseks jäänud kokaraamatus (Tannbaum 1937: 207).

Kuidas Adeline Tannbaum seakõrvade retseptini jõudis, võib vaid oletada. Ta võis seda näha vanades kokaraamatutes või puutus nende valmistamisega kok-

[4] Võimalik, et säärane nimetus oli ajendatud teatud välisest sarnasusest sea kõrvaga. 
ku kokakoolis. Nimelt asutas aastal 1894 Riias oma kokakooli Marra Korth, kelle juures õppis ka Adeline Tannbaum. Korth koostas ja avaldas retseptikogu „Praktisches Kochbuch", millest anti välja mitu kordustrükki. Tema raamatus esineb rasvaküpsetiste retsept, milles võib eksimatult ära tunda klenät'id ehk rattakoogid ehk seakõrvad. Korthil kannavad need aga hoopis Hanschkuchen'i nimetust. Koogid valmistati munast, vahukoorest, võist, jahust ja suhkrust. Tainas rulliti noaselja paksuseks ning lõigati kahe sõrme laiusteks ja sõrmepikkusteks tükkideks, mille keskele tehti sisselõige ning tõmmati koogi üks ots sealt läbi. Küpsetamiseks soovitati võtta (veise)neerurasva või rasva pooleks võiga, valmis koogid aga puistata üle tuhksuhkruga (Korth 1911: 418).

Siiski polnud Tannbaum kaugeltki ainus, kes 20. sajandi algul seakõrvade retsepti eestlastele vahendas. 1913. aastal avaldas selle ka Emma Leesment-Mälberg (1886-1940) „Perenaeste käsiraamatus”. Ta oli õppinud Soomes Reitkalli aiandusja majapidamiskoolis ning tegutses Eestis Põhja-Liivimaa Põllutöö Keskseltsi kodumajanduse instruktorina. Leesment-Mälbergi retsept on Tannbaumiga sarnane, kuid veelgi lihtsam, maitsestatud ainult suhkruga (Leesment-Mälberg 1913: 56).

Eesti esimese iseseisvusaja kokaraamatutes laialt levinud seakõrvade valmistamise õpetus kandus edasi ka nõukogude aja kokaraamatutesse. Tegu on ju üsna lihtsa küpsetisega, mille koostisosad olid üldiselt isegi tollase defitsiidimajanduse tingimustes kättesaadavad. Probleemiks võis kujuneda ainult maitsestamine, sest kättesaadavate maitseainete valik oli väike. Ida Savi soovitab raamatus "Saiad, pirukad, koogid" seakõrvu maitsestada viina või konjakiga ning kardemoni puudumisel riivitud sidrunikoorega, panustades sellega kahtlemata ühele kõige kättesaadavamale ainele - alkoholile (Savi 1989: 129). Seakõrvad jäid peamiselt kodusteks küpsetisteks, erinevalt näiteks sõõrikutest, mida müüdi pontšikubaarides. Tänases Eesti köögis ei ole seakõrvade küpsetamine enam kuigi tavaline ja levinud. Keskealiste põlvkond meenutab seakõrvu nostalgiliselt kui lapsepõlvest tuttavaid küpsetisi. ${ }^{5}$ Nende menüüst kadumisele on kindlasti mõju avaldanud asjaolu, et nüüdisajal ei peeta rasvaküpsetisi kuigi tervislikeks. Siiski jagatakse nii ajakirjanduses kui ka toidublogides ja foorumites õpetusi seakõrvade valmistamiseks, lisaks tavapärasele võib leida ka pärmiga tehtud taignast seakõrvade retsepti (Vahtramäe 2013), mis on tuntud mitmel pool Saksamaalgi (Schürzkuchen).

Rootsis on klenät'ide näol tegu traditsioonilise jõuluaja küpsetisega, selle eeskujul seostatakse tänapäeval Eestis seakõrvu samuti just jõuludega (Vahtramäe 2013). 1511. aastal valmistati Tallinnas paganate kooke vastlapeoks. Kas see oli või sellest kujunes pikemaajalisem traditsioon, sellele pole allikad seni vastust andnud. Saksamaal on nn sõlmitud koogid (Schürzkuchen, vt eespool) muu hulgas tuntud kui (vastla)karnevali maiustused. Arvestades algupäraselt paganate kookide nime all tuntud küpsetiste püsimist Eesti köögis läbi sajandite, tundub kõigiti tõenäoline, et seda kestmist toetas mingi traditsioon, st neid tehti kas vastlate, jõulude või mõne teise tähtpäeva tähistamiseks.

[5] Lapsepõlves sai nende hõrkude küpsiste pärast pensionäride sünnipäevadel käidud küll ja küll! „Efka“ kommentaar Toidutare seakõrvade retseptile, http://toidutare.ee/peotoidud/ j\%C3\%B5ulud/E662/ (viimati külastatud 26.04.2017). 


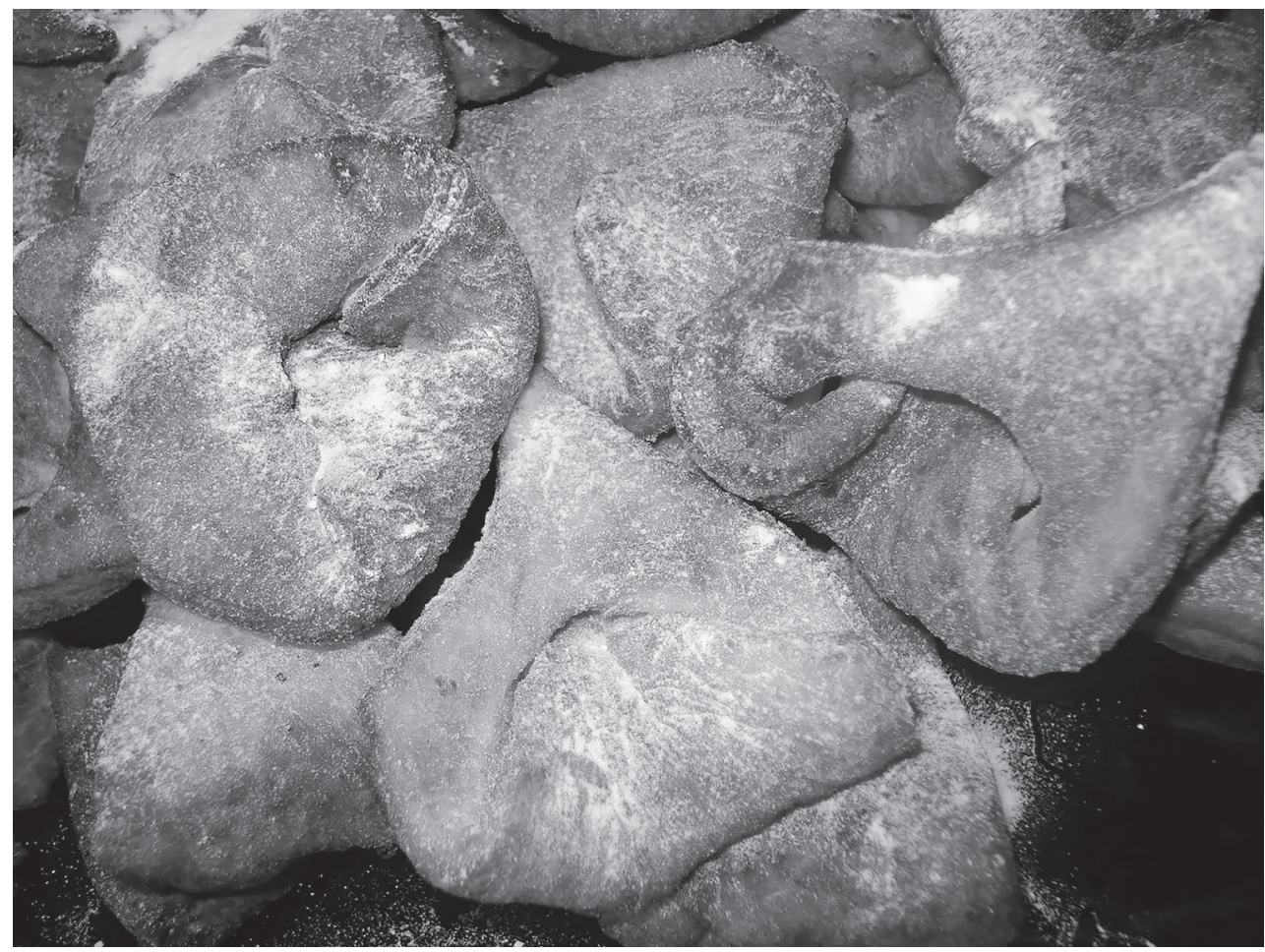

Foto 4. Tänapäevased seakõrvad.

Allikas: Krisly Köögis

\section{Kokkuvõte}

Kirjalike teadete, peamiselt retseptikogude ja kokaraamatute abiga joonistub välja ühe toidu märkimisväärne teekond Eesti köögis läbi sajandite. Keskaja Euroopa kokaraamatutes esines paganate kookide nime all vähemalt kaks täiesti erinevat rooga, kuid mõlemal juhul oli tegu idamaa toitudest võetud eeskujuga. Tõenäoliselt hansakaupmeeste vahendusel jõudsid paganate koogid Tallinna resp. Eesti peenesse kööki. Pole lõpuni selge, kas juba keskajal kodunes Eestis ainult üks paganate kookide retsept. Igal juhul jäid paganate koogid Eesti peenesse kööki mitmeks sajandiks püsima. Just selle nime all tundis kohalik baltisaksa köök munataignast rasvaküpsetisi veel 19. sajandi algul.

Alates 18. sajandist on võimalik jälgida nende küpsetiste kohanemise lugu Eesti köögis kokaraamatute vahendusel. Vanad retseptikogud dokumenteerivad paganate kookide valmistamistraditsioonis toimunud muutusi ja arengut. Nende küpsetamise tavad ei kandunud edasi ainult ajas, vaid liikumine toimus ka ühiskonnasiseselt, sotsiaalseid ja seisuslikke piire ületades. Varem eliidi menüüsse kuulunud roog jõudis 19. sajandi lõpul ja 20. sajandi algul lihtsa inimese toidulauale. Eesti oludes tähendas see muuhulgas liikumist üle rahvuse piiride, s.o saksa eliidi laualt eestlastest lihtrahva menüüsse. Kokaraamatutest ja -kursustest tugevalt dikteeritud 
ja suunatud kohanemisprotsessi käigus muutus korduvalt roa nimi (heydenssche koken, klenätid, Räderkuchen, rattakokid, seakõrvad), samuti toimusid muutused maitsenüanssides (liikumine teravamatelt, tugevamatel maitsetelt mahedamatele) ning isegi kookide väljanägemises. Paganate kookide ehk seakõrvade lugu Eesti köögis demonstreerib, kui pikk ja käänuline võis olla ühe algselt eliidi menüüsse kuulunud roa teekond rahva toidulauale. Taoliste rahvusvaheliste retseptide kodunemise või kohanemise uurimine ajaloolises Eesti köögis annab muu hulgas hea võimaluse leida ja tuua esile selle eripärasid ning määratleda täpsemalt mõjuvälju, milles see on kujunenud.

\section{Allikad}

EAA f 1862 = Eesti Ajalooarhiiv, Perekond Stackelbergi fond n 1, s 90: Kochbuch, 1740(?).

TLA f 230 = Tallinna Linnaarhiiv, Tallinna magistraadi fond, n 1, s Ad 32: Städtische Kämmerei-Rechnungen 1507-1533.

TLA f 230 = Tallinna Linnaarhiiv, Tallinna magistraadi fond, n 1. s Aa 44: Protokolle des Niedergerichts 1600-1603.

TLA f 230 = Tallinna Linnaarhiiv, Tallinna magistraadi fond, n 1, s Ba 6: Rechnungen des Rats $1400-1693$.

TLA f 191 = Tallinna Linnaarhiiv, Tallinna Kaupmeeste ehk Suurgildi fond, n 2, s 19: Maigrafenbuch 1527-1543.

\section{Kirjandus}

Albala, Ken. 2012. Cookbooks as historical documents. - The Oxford Handbook of Food History, ed. by Jeffrey M. Pilcher, New York: Oxford University Press, 227-240.

Bunge, Friedrich Georg von, Paucker, Carl Julius Albert (Hrsg.). 1851. Archiv für die Geschichte Liv-, Esth- und Curlands. Bd. VI. Reval.

Dumpe, Linda. 1998. Aus der baltischen Kochengeschichte. Die ersten lettischen Kochbücher. - Kultuuri mõista püüdes / Trying to Understand Culture, toim. Terje Anepaio, Aivar Jürgenson, Scripta ethnologica 3. Tallinn: Teaduste Akadeemia Kirjastus, 233-245.

[Fehre, Katharina.] 1824. Uus Kögi- ja Kokka ramat. Tallinn: P. C. G. Dullo.

Gloning, Thomas (toim). 2001. Das buoch von guoter spise. http://www.staff.uni-giessen.de/ gloning/tx/bvgs.htm (viimati külastatud 20.04.2017).

Korth, Marra. 1911. Praktisches Kochbuch. Riga: C. J. Sichmann.

Krisly Köögis. "Seakõrvad". http://krisly-krisly.blogspot.com.ee/2010/08/seakorvad.html (viimati külastatud 26.04.2017).

Küpsised - seakõrvad. Nami-nami http://www.nami-nami.ee/retsept/356/seakorvad_rasvakupsised (viimati külastatud 26.04.2017).

Leesment-Mälberg, Emma. 1913. Perenaeste käsiraamat. Tartu: Eesti Põllutöö kirjanduse Ühendus.

Montanari, Massimo. 1999. Der Hunger und der Überfluss. Kulturgeschichte der Ernährung in Europa. München.

Moora, Aliise. 1991. Eesti talurahva vanem toit. 2. osa: Joogid. Leib ja leivakõrvane. Tallinn: Valgus. 
Panck, Lyda. 1862. Kochbuch für die deutschen Ostseeprovinzen Russlands. Dorpat: Verlag von E. J. Karow.

Panck, Lyda. 1864. Kasulinne kögi- ja majapiddamisseramat. Tartu: E. J. Karow.

Marahwa Näddala-Leht 1825, nr. 15 (15. aprill), 118-120.

Praktisches Mitauer Kochbuch 1844. Mitau: Verlag von Friedrich Gustav Lucas.

Põltsam-Jürjo, Inna. 2012. „Hääleib”, „,saajaleib”, „ißeleib” - Eesti leivakultuurist 13.-16. sajandil. - Tuna 4, 14-28.

Põltsam-Jürjo, Inna. 2013. Pidusöögist näljahädani. Söömine-joomine keskaja Tallinnas. Tallinn: Hea Lugu.

Schubert, Ernst. 2006. Essen und Trinken im Mittelalter. Darmstadt: Wissenschaftliche Buchgesellschaft.

Seakõrvad. Toidutare. http://toidutare.ee/peotoidud/j\%C3\%B5ulud/E662/ (viimati külastatud 26.04.2017).

Tannbaum, Adeline. 1914. Keedukursus. Tartu: Postimees.

Tannbaum, Adeline. 1927. Taimevõi majapidamises. Tartu, Tallinn: Tallinna Eesti KirjastusÜhisus.

Tannbaum, Adeline. 1937. Keedu- ja majapidamisjuht "Moodne perenaine“. Tartu: Postimees.

Wahl, Henriette von. 2014. Kochbuch. Anno 1800. Marburg: Familienverband von Wahl.

Warg, Christina. 1755. Hijlpreda i hushållningen för unga fruentimber. Stockholm: Grefingska Tryckeriet.

Warg, Christina. 1772. Schwedisches Koch- und Hauzshaltungs-Buch. Greifswald: Verlag von A. F. Röse

[Warg, Christina.] 1781. Köki ja Kokka ramat, mis Rootsi kelest Eesti-ma Kele üllespandud on. Tõlk. Johann Lihtander. Tallinn: A. H. Lindfors.

Wiswe, Hans; Hepp, Eva. 1970. Kultugeschichte der Kochkunst. Kochbücher und Rezepte aus zwei Jahrtausenden. München: Moos.

Vahtramäe, Ell. 12.12.2013. Jõulumaiuseks tee seakõrvad. Maablogi. https://maablogi.wordpress.com/2013/12/12/joulumaiuseks-tee-seakorvad/ (viimati külastatud 26.04.2017).

Viires, Ants. 1985. Kokaraamatud kultuuriloo kajastajatena. - Keel ja Kirjandus 3, 158-166.

Wackernagel, Wilhelm 1853. Kochbuch von Maister Hannsen des von Wirtenberg Koch. Zeitschrift für deutschen Alterthum 9, 365-373.

Inna Põltsam-Jürjo on TLÜ ajaloo, arheoloogia ja kunstiajaloo keskuse vanemteadur, peamiseks uurimisvaldkonnaks kesk- ja varauusaja linnaajalugu ja argikultuur; avaldanud muu hulgas raamatu „Pidusöögist näljahädani. Söömine-joomine keskaja Tallinnas" (2013). 
Inna Põltsam-Jürjo

\section{Summary: From "heathens' cakes" to "pig's ears": tracing a food's journey across cultures, centuries and cookbooks}

\section{Inna Põltsam-Jürjo}

It is intriguing from the perspective of food history to find in 19th and 20th century Estonian recipe collections the same foods - that is, foods sharing the same names found back in European cookbooks of the 14th and 15th centuries. It is noteworthy that they have survived this long, and invites a closer study of the phenomenon. For example, 16th century sources contain a record about the frying of heathen cakes, a kind of fritter, in Estonia. A dish by the same name is also found in 18th and 19th century recipe collections. It is a noteworthy phenomenon for a dish to have such a long history in Estonian cuisine, spanning centuries in recipe collections, and merits a closer look.

Medieval European cookbooks listed two completely different foods under the name of heathen cakes and both were influenced from foods from the east. It is likely that the cakes made it to Tallinn and finer Estonian cuisine through Hanseatic merchants. It is not ultimately clear whether a single heathen cake recipe became domesticated in these parts already in the Middle Ages. In any case, heathen cakes would remain in Estonian cuisine for several centuries. As late as the early 19th century, the name in the local Baltic German cuisine referred to a delicacy made of egg-based batter fried in oil.

Starting from the 18th century, the history of these fritters in Estonian cuisine can be traced through cookbooks. Old recipe collections document the changes and development in the tradition of making these cakes. The traditions of preparing these cakes were not passed on only in time, but circulated within society, crossing social and class lines. Earlier known from the elites' culture, the dish reached the tables of ordinary people in the late 19th and early 20th century. In Estonian conditions, it meant the dish also crossed ethnic lines - from the German elite to the Estonian common folk's menus. In the course of adaptation process, which was dictated and guided by cookbooks and cooking courses, the name of the dish changed several times (heydenssche koken, klenätid, Räderkuchen, rattakokid, seakõrvad), and changes also took place in the flavour nuances (a transition from spicier, more robust favours to milder ones) and even the appearance of the cakes. The story of the heathen cakes or pig's ears in Estonian cuisine demonstrates how long and tortuous an originally elite dish can be as it makes its way to the tables of the common folk. The domestication and adaptation of such international recipes in the historical Estonian cuisine demonstrates the transregional cultural exchange, as well as culinary mobility and communication. 


\section{Резюме: От языческих пирогов до свиных ушей. Транскультурное путешествие по следам одного блюда сквозь века и поваренные книги.}

\section{Инна Пылтсам-Юрьё}

С точки зрения истории питания интригующим является обнаружение в сборниках рецептов XIX-XX века тех же самых т.е. с теми же самыми названиями блюд, которые представлены и в поваренных книгах Европы XIV-XV века. Такое постоянство на протяжении времени заслуживает внимания, побуждая к более подробному исследованию явления. Например, в источниках XVI века можно найти информацию о том, что в Эстонии готовиди т.н. языческие пироги. Блюдо с таким же названием встречается также в сборниках рецептов XVIII-XIX века. Столь долгая история одного блюда в эстонской кухне, его присутствие в сборниках рецептов на протяжении столетий является заслуживающим внимания феноменом, который требует детального изучения.

В поваренных книгах средневековой Европы под именем «языческий пирог» фигурировало по меньшей мере два совершенно разных блюда, но в обоих случаях имелось дело с перенятым из восточной кухни образцом. Вероятно, через ганзейских купцов языческие пироги появились в Талдинне, а тем самым и в более утонченной эстонской кухне. До конца не известно прижился ли в средние века здесь только один рецепт языческих пирогов. В любом случае языческие пироги сохранялись в эстонской кухне на протяжении нескольких столетий. Именно под таким названием в местной кухне прибалтийских немцев была известна выпечка из яичного теста в жире еще в начале XIX века.

Начиная с XVIII века можно проследить историю того, как через поваренные книги эта выпечка приспосабливалась к эстонской кухне. Собрания старых рецептов документируют изменения и развитие происходившее в традиции изготовления языческих пирогов. Традиции их выпечки не распространялись только во времени, но движение происходило и внутри общества, пересекая социальные и сословные границы. Входившее раньше в меню элиты блюдо в конце XIX, начале XX века появилось на столе простых людей. В эстонских условиях это, среди прочего, означало и пересечение национальной границы, т.е. со стола немецкой элиты в меню простых эстонцев. В ходе сильно насаждаемого и направляемого поваренными книгами и кулинарными курсами процесса адаптации неоднократно менялось название блюда (heydenssche koken, klenätid, Räderkuchen, круглые пироги, свиные уши), изменения также произошли и во вкусовых нюансах (движение от острых и резких вкусов к более нежным), и даже во внешнем виде выпечки. История языческих пирогов или «свиных ушей» в Эстонии демонстрирует каким долгим и извилистым мог быть путь одного, входящего в меню элиты бдюда до стола простого народа. Подобное приспособление международных рецептов и их вхождение в обиход эстонской кухни демонстрирует трансрегиональный культурный обмен, а также кулинарную мобильность и коммуникацию. 